\title{
ANTIBIOTIC RESISTANCE AND R FACTORS IN COLIFORM BACILLI ISOLATED FROM HOSPITAL AND DOMESTIC SEWAGE
}

\author{
K. B. Linton, M. H. Richmond, Rosemary Bevan and \\ W. A. GILlespie \\ Department of Bacteriology, University of Bristol, BS8 ITD
}

Previous studies in this laboratory and elsewhere have shown that intestinal bacteria carrying $\mathrm{R}$ factors (antibiotic-resistance-transfer factors) are widespread in the environment. Of 193 townspeople examined in a survey of healthy adults and children in Bristol who were not attending hospital nor had recently received antibiotics, $53 \%$ carried detectable antibiotic-resistant coliform bacilli in their faeces, and in $61 \%$ of these, $\mathrm{R}$ factors were demonstrated (Linton et al., 1972). Similarly, Datta (1969) examined faecal samples collected before admission from patients arriving at hospital for non-urgent surgical operations and found that $52 \%$ contained antibiotic-resistant Escherichia coli. About $60 \%$ of the resistant strains were shown to carry $\mathrm{R}$ factors and multipleresistance patterns were commoner than single. Moorhouse (1969) examined faecal coliforms in healthy infants in Dublin; the samples were collected by health visitors and all children who had any history of antibiotic treatment were excluded from the survey. Nevertheless, antibiotic-resistant enterobacteria were detected in $81 \%$ of the subjects examined; $84 \%$ of the resistant strains were shown to possess $\mathrm{R}$ factors, and in more than half of these samples the resistant organisms constituted the majority of the bacteria.

In these studies, of necessity, only few individuals could be examined, and consequently it may be unwise to make wide generalisations from the findings about the incidence of $\mathrm{R}$ factors in the population at large. We have now attempted to make a broader analysis by studying the composition of pooled sewage derived from different localities. Some sections of the Bristol sewerage system were particularly well suited to this purpose because it was possible to obtain samples from relatively circumscribed localities-for example from residential housing estates and, separately, from hospitals in the same areasand therefore to compare the output of antibiotic-resistant and R-factorcarrying bacteria from them. Repeated samples were taken from the outflow from three hospitals and two adjacent housing estates, and from the point where the pooled city sewage entered the sewage-treatment works.

The results reported here are limited to aerobic, lactose-fermenting, Gramnegative bacilli capable of growing on MacConkey's bile-salt-lactose agar, and called " coliform bacilli" throughout this paper. Many of the coliform bacilli from all types of sewage could not be identified by the methods used and because

Received 9 Apr. 1973; accepted 4 June 1973.

J. MED. MICROBIOL.-VoL. 7 (1974) 
they may have been of soil or vegetable origin, some comparisons reported here are restricted to the frankly faecal organism, E. coli type I. Many of the coliform bacilli commonly found in rain-water drains and sewers were intrinsically ampicillin-resistant. Therefore, although ampicillin resistance was recorded, we do not consider it as good a guide to the influence of antibiotic usage as resistance to the other antibiotics used in our tests.

The results showed that although the sewage from hospitals contained much higher proportions of resistant coliform bacilli and of R-factor-carrying strains than that from domestic premises, more than $90 \%$ of the resistant organisms and more than $90 \%$ of the $\mathrm{R}$ factors in pooled sewage from the whole city were probably derived from people living outside hospitals. This somewhat unexpected distribution has important implications when we consider the role of $\mathbf{R}$ factors in changing the populations of antibiotic-resistant bacteria in a community.

\section{MATERIALS AND METHODS}

Sampling sites. From Feb. 1971 to June 1972, a programme of investigation was arranged with the Bristol City Engineer's Department. This included three periods, each of about 2 months, during which sewage samples were examined. The first two sampling periods enabled information to be obtained from the same sewers in winter and in summer; the third period was used to repeat samples from certain sites to confirm some of the more interesting earlicr observations.

Sampling was concentrated in three areas A, B, and C on the north-east outskirts of Bristol, about 10 miles from the sewage-treatment works which were near the mouth of the River Avon. The sewers selected in these areas included one draining the whole area, one that drained dwelling-houses only, and one from each of several hospitals; each of these sites was investigated during the first sampling period and repeated during the third period. The hospitals in areas A and B were large general hospitals; that in area C was a large mental hospital. Samples were also taken from six other areas, chosen because they contained sites of potential interest, e.g., a zoo, an abattoir, etc. Throughout all three periods, a weekly sample was obtained at the inlet to the treatment works which processed about $60 \%$ of the city sewage-about 21 million gallons $\left(100,000 \mathrm{~m}^{3}\right)$ daily. These samples were intended to provide regular estimates of the total output of sewage and to indicate variations in the bacterial content of pooled sewage and any inconsistencies in the sampling method.

Sewer samples. Sewer swabs were prepared by rolling half of a no. 1 Hosezene sanitary towel and tying it to $5 \mathrm{~m}$ of thick string; the swab and string were packed in a glass jar and sterilised. For sampling, the string was tied to a manhole step or other fixture so that the swab remained immersed just below the surface of the sewage. Preliminary tests were made with dry swabs and swabs moistened with sterile water before use, and comparing different times of exposure. The most consistent results were obtained with dry swabs exposed for 24 hours. Laboratory tests performed at temperatures similar to those found in sewers showed that the count of coliform bacilli remained fairly constant in sewage for several days with only slight multiplication of an occasional strain, and a very slow total death rate. Swabs were therefore collected after exposure for $\mathbf{2 4}$ hours, replaced in the jar and taken immediately to the laboratory where fluid was squeezed from the swab and examined within a few hours.

Direct plating and antibiotic-sensitivity tests. The fluid from the sewer swab was inoculated directly on to three MacConkey plates; one was streaked to obtain individual colonies to give an indication of the main types of organism present; a moistened swab was used to inoculate the other two plates to obtain a uniform inoculum for direct sensitivity tests with a "Multodisk" (Oxoid) and three additional disks. The disks contained ampicillin $(25 \mu \mathrm{g})$, streptomycin $(25 \mu \mathrm{g})$, tetracycline $(50 \mu \mathrm{g})$, kanamycin $(30 \mu \mathrm{g})$, nalidixic acid $(30 \mu \mathrm{g})$, chloramphenicol $(50 \mu \mathrm{g})$, nitrofurantoin $(200 \mu \mathrm{g})$, sulphafurazole $(500 \mu \mathrm{g})$, carbenicillin $(25 \mu \mathrm{g})$, cephaloridine $(25 \mu \mathrm{g})$ and gentamicin $(10 \mu \mathrm{g})$. A roughly quantitative system of recording 
was used to note the types of organism and the amount of growth on the direct plate and around each antibiotic disk.

Viable counts were made by preparing serial ten-fold dilutions from $10^{-1}$ to $10^{-6}$. A standard volume of each dilution was then inoculated on duplicate plates of five mediaMacConkey agar alone, or incorporating $25 \mu \mathrm{g}$ per $\mathrm{ml}$ of either ampicillin, tetracycline, streptomycin, or chloramphenicol.

For some samples the standard volume was $0.025 \mathrm{ml}$, but when replica plating was to be done, $0 \cdot 1 \mathrm{ml}$ was spread over the whole of each plate.

After incubation at $37^{\circ} \mathrm{C}$ overnight, colonies of coliform bacilli on appropriate plates were counted.

Replica plating was performed by sterile velvet pad from antibiotic-containing plates showing 20-50 well-spaced colonies to plates containing each antibiotic in turn, and finally to a MacConkey plate without antibiotic to check that replication was satisfactory. The resistance pattern of each colony to the four antibiotics tested in this way was noted by comparison with the master plate and, where possible, an estimate was made of the number of organisms in the sewage with each sensitivity pattern.

Clearer results were often obtained by subculturing up to 16 colonies from the primary viable-count plate to another plate of the same medium, marked with a grid. With this plate as the master, replica plating was performed as above.

$R$-factor transfer was assessed by the method used previously (Linton et al., 1972).

Identification of lactose-fermenting coliform bacilli. Twelve colonies were picked from each primary plate culture to represent the predominant flora. These, and up to 64 cultures of resistant colonies from each sample selected during replica plating and tests for $\mathrm{R}$ factors, were identified by testing for indole production at $44^{\circ} \mathrm{C}$ and gas production from lactose ricinoleate broth at $44^{\circ} \mathrm{C}$ (Department of Health and Social Security, 1969). Strains that gave positive reactions in both tests were grouped as $E$. coli type I. The remainder were grouped into Klebsiella, Enterobacter, Citrobacter, or " others " by the following tests: fermentation of adonitol and inositol, utilisation of malonate and gluconate, growth in citrate, and methylred, Voges-Proskauer, $\mathrm{H}_{2} \mathrm{~S}$ - and urease-production (Cowan and Steel, 1965).

\section{RESULTS}

\section{Viable counts of coliform bacilli in sewers}

Coliform bacteria from hospital sewers were compared with those from sewers draining the adjacent housing estates and from the inlet to the sewagetreatment works (table I). The total counts of coliform bacilli in each millilitre of fluid expressed from the swabs were surprisingly constant in all samples from the same sources even at different seasons, and so are presented as average values for each type of sewer. Coliform counts from hospital sewers were consistently higher than those from other sites, whereas counts at the inlet to the treatment works were always slightly lower than elsewhere. This latter observation may have been caused by the death of some organisms during their passage through the sewers or to dilution with rain-water and water from industrial channels.

The bacterial counts in sewage from other areas of interest-rural sewers, trunk sewers, zoo, etc.-will be described in another paper. On average, they were similar to those in domestic sewage (table I).

\section{Identity of predominant coliform bacilli in sewage}

From cultures of 23 sewer samples on MacConkey agar without antibiotics, 945 lactose-fermenting colonies were picked and identified as far as possible. 
These colonies indicated the predominant types of coliform bacilli in the sewage; the results are given in table II. Of these isolates, $40 \%$ could not be fully identified by the tests employed: Klebsiellae were the commonest $(33 \%) ; E$. coli type I constituted only $12.6 \%$ of the organisms isolated. The proportions of the different types were fairly constant in sewers from all sites except that relatively fewer strains of $E$. coli type I were found in sewage from hospitals than from elsewhere.

\section{Antibiotic-resistant coliform bacilli}

Unlike other bacteria, ampicillin-resistant ones fluctuated widely in numbers on different days in the same sewers. Their average numbers were high in almost

TABLE I

Antibiotic-resistant coliform bacilli isolated from sewage

\begin{tabular}{|c|c|c|c|c|c|c|}
\hline \multirow[b]{2}{*}{ Source } & \multirow{2}{*}{$\begin{array}{c}\text { Number } \\
\text { of } \\
\text { samples }\end{array}$} & \multirow{2}{*}{$\begin{array}{l}\text { Total } \\
\text { coliform } \\
\text { count } \\
\text { per ml } \\
\text { (geo. mean) }\end{array}$} & \multicolumn{4}{|c|}{ Percentage of coliform bacilli resistant to } \\
\hline & & & $\begin{array}{l}\text { ampi- } \\
\text { cillin }\end{array}$ & $\begin{array}{l}\text { strepto- } \\
\text { mycin }\end{array}$ & $\begin{array}{l}\text { chloram- } \\
\text { phenicol }\end{array}$ & $\begin{array}{l}\text { tetra- } \\
\text { cycline }\end{array}$ \\
\hline Domestic sewers & 23 & $8 \cdot 7 \times 10^{6}$ & $48 \cdot 4$ & $6 \cdot 2$ & 0.2 & $3 \cdot 2$ \\
\hline $\begin{array}{l}\text { Hospital* sewers } \\
\text { general } \\
\text { mental }\end{array}$ & $\begin{array}{r}16 \\
2\end{array}$ & $\begin{array}{l}1.6 \times 10^{7} \\
3.5 \times 10^{7}\end{array}$ & $\begin{array}{r}36 \cdot 4 \\
6 \cdot 2\end{array}$ & $\begin{array}{r}37 \cdot 0 \\
9 \cdot 5\end{array}$ & $\begin{array}{l}0.4 \\
0.03\end{array}$ & $\begin{array}{r}18 \cdot 8 \\
0.4\end{array}$ \\
\hline Other sewers $\dagger^{\dagger}$ & 31 & $4.8 \times 10^{5}$ & $38 \cdot 3$ & $6 \cdot 3$ & $0 \cdot 1$ & $1 \cdot 2$ \\
\hline $\begin{array}{l}\text { Inlet to sewage- } \\
\text { treatment works }\end{array}$ & 29 & $5.6 \times 10^{6}$ & $40 \cdot 8$ & 6.5 & 0.3 & 1.7 \\
\hline
\end{tabular}

* Most hospital sewers also served some domestic premises.

$\uparrow$ Sewers serving an abbattoir, a zoo, trunk sewers, rivers, and streams.

all areas, perhaps because intrinsically ampicillin-resistant bacteria were common in land drainage water. The proportion of such water in sewage naturally fluctuated widely.

Coliform bacilli resistant to streptomycin, chloramphenicol, or tetracycline were detected in all the samples but were more numerous from hospitals than from other sources, including adjacent housing estates (table I). Of the eight hospitals that were studied, seven were general hospitals ranging from 60 to 600 beds; the incidence of coliform bacilli resistant to streptomycin, chloramphenicol, or tetracycline was very much higher in their sewers than in those from nearby domestic areas. By contrast, the sewers from a mental hospital of 840 beds contained no more antibiotic-resistant coliforms than the adjacent domestic sewers.

Most of the hospital sewers also drained some nearby houses, and some domestic areas included small nursing homes, but three hospitals in the areas $\mathrm{A}, \mathrm{B}$, and $\mathrm{C}$ were drained by isolated sewers and these were studied in more detail. Sewage from these three hospitals was tested on several occasions; and 


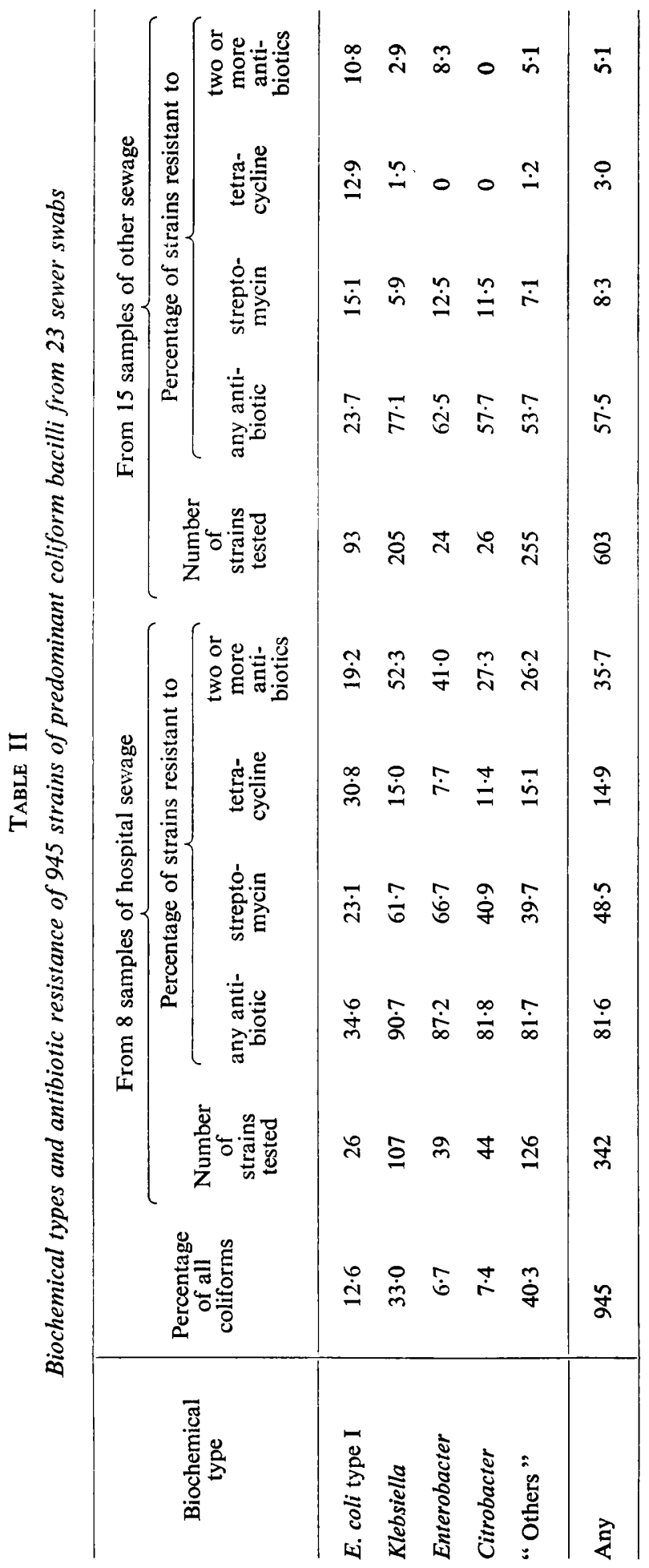


on the same days swabs were obtained from isolated sewers serving nearby housing estates occupied by about the same number of people as the corresponding hospitals. The differences already described between the proportions of coliform bacilli resistant to streptomycin, chloramphenicol, or tetracycline in hospital and domestic sewers were seen more clearly in samples from areas A and B, both of which included a hospital. Table III presents the results for samples from the same sites; all pairs of samples, from hospital and domestic sewers, collected during a period of 10 months, consistently showed these differences. Thus about $40 \%$ of the coliform bacilli in sewers from hospitals $\mathrm{A}$ and $B$ were resistant to streptomycin compared with $3.5 \%$ for the adjacent domestic sewers sampled simultaneously. Similar differences were found for

TABLE III

Antibiotic-resistant coliform bacilli from sewers serving isolated premises

\begin{tabular}{|c|c|c|c|c|c|c|c|}
\hline \multirow[b]{2}{*}{ Area } & \multirow{2}{*}{ Premises } & \multirow{2}{*}{$\begin{array}{l}\text { Number } \\
\text { of } \\
\text { samples }\end{array}$} & \multirow{2}{*}{$\begin{array}{c}\text { Total } \\
\text { coliform } \\
\text { count } \\
\text { per } \mathrm{ml}^{*}\end{array}$} & \multicolumn{4}{|c|}{ Percentage of coliform bacilli resistant to } \\
\hline & & & & $\begin{array}{c}\text { ampi- } \\
\text { cillin }\end{array}$ & $\begin{array}{l}\text { strepto- } \\
\text { mycin }\end{array}$ & $\begin{array}{l}\text { chloram- } \\
\text { phenicol }\end{array}$ & $\begin{array}{l}\text { tetra- } \\
\text { cycline }\end{array}$ \\
\hline $\mathbf{A}$ & $\begin{array}{l}\text { Hospital } \\
\text { Domestic }\end{array}$ & $\begin{array}{l}3 \\
3\end{array}$ & $\begin{array}{l}6.5 \times 10^{7} \\
4.0 \times 10^{6}\end{array}$ & $\begin{array}{l}23 \cdot 2 \\
46 \cdot 7\end{array}$ & $\begin{array}{r}48.8 \\
0.6\end{array}$ & $\begin{array}{l}0.4 \\
0.007\end{array}$ & $\begin{array}{r}24 \cdot 3 \\
0 \cdot 1\end{array}$ \\
\hline $\begin{array}{l}\text { B } \\
\text { BC } \\
\text { C }\end{array}$ & $\begin{array}{l}\text { Hospital } \\
\text { Domestic } \\
\text { Hospital }\end{array}$ & $\begin{array}{l}3 \\
3 \\
2\end{array}$ & $\begin{array}{l}5.0 \times 10^{7} \\
1 \cdot 3 \times 10^{7} \\
3.5 \times 10^{7}\end{array}$ & $\begin{array}{r}25 \cdot 4 \\
22 \cdot 8 \\
6 \cdot 2\end{array}$ & $\begin{array}{r}34 \cdot 7 \\
6 \cdot 5 \\
9 \cdot 5\end{array}$ & $\begin{array}{l}0.7 \\
0.02 \\
0.03\end{array}$ & $\begin{array}{r}32 \cdot 0 \\
1.3 \\
0.4\end{array}$ \\
\hline
\end{tabular}

Hospitals A and B: large general hospitals. Hospital C: large mental hospital.

* Geometric mean.

chloramphenicol-hospital $0.54 \%$; domestic $0.015 \%$-and tetracyclinehospital $28.2 \%$; domestic $0.7 \%$. From hospital C, a large mental hospital with an isolated sewer, the incidence of antibiotic-resistant coliform bacilli in sewage samples was very similar to that in the nearby domestic area BC.

These findings may be explained by the large differences in the quantities of antibiotics prescribed in the two types of hospital. Annual figures for the antibiotics used from Apr. 1971 to Mar. 1972 were available for seven of the eight hospitals and show that a much wider variety and many more courses of antibiotics were prescribed in the general hospitals than in the mental hospital. The average annual cost, per occupied bed, of antibiotics active against Gramnegative bacilli was $£ 19.78$ for general hospitals and $£ 0.30$ for the mental hospital. Calculation of the corresponding total weight of each antibiotic confirmed the large difference between antibiotic usage in these hospitals.

\section{Antibiotic resistance in coliform bacilli of different biochemical types}

All biochemical types of coliform bacilli isolated from hospital sewers were found to include a higher proportion of strains resistant to antibiotics than the same types from other sewers. Multiple resistance-to two or more antibiotics 
-was also commoner in all coliform bacilli from hospitals than in the same types from elsewhere and this was most marked in types other than $E$. coli type I: hospital isolates $37 \%$; other isolates $4 \%$.

Resistance to streptomycin and to tetracycline in each type of coliform is shown in table II. Only one of the 945 cultures of predominant organisms was resistant to chloramphenicol; $55.6 \%$ were resistant to ampicillin and most of these were Klebsiellae and unidentifiable coliform bacilli from all sources.

In addition to the 626 antibiotic-resistant strains from cultures on MacConkey agar without antibiotics (predominant strains), another 2087 colonies were picked from cultures of the same 23 sewer samples on media containing one of four antibiotics. The resistance of the predominantprobably non faecal-types of coliform bacilli to chloramphenicol and tetracycline was relatively low and cultures on media containing these antibiotics

TABLE IV

Resistance to antibiotics of coliform bacilli from 23 sewer swabs on media containing antibiotics

\begin{tabular}{l|cccccc}
\hline \multirow{2}{*}{ Coliform type } & $\begin{array}{c}\text { Total } \\
\text { number } \\
\text { of } \\
\text { strains }\end{array}$ & $\begin{array}{c}\text { ampi- } \\
\text { cillin }\end{array}$ & $\begin{array}{c}\text { strepto- } \\
\text { mycin }\end{array}$ & $\begin{array}{l}\text { chloram- } \\
\text { phenicol }\end{array}$ & $\begin{array}{c}\text { tetra- } \\
\text { cycline }\end{array}$ & $\begin{array}{c}\text { Percentage } \\
\text { of strains } \\
\text { multi } \\
\text { resistant* }\end{array}$ \\
\hline Esch. coli type I & 745 & 41.6 & 63.6 & $38 \cdot 3$ & $82 \cdot 7$ & $70 \cdot 0$ \\
Others & 1968 & 84.5 & $54 \cdot 1$ & 4.3 & $29 \cdot 4$ & $50 \cdot 1$ \\
\hline
\end{tabular}

* To two or more antibiotics.

therefore yielded a high proportion of faecal type $E$. coli. The pattern of antibiotic resistance was very similar in all biochemical coliform types except $E$. coli, and the findings for these are shown in table IV; chloramphenicol and tetracycline resistance was much more common in $E$. coli than in other coliform types while in the latter strains the high incidence of ampicillin resistance and the lower proportion of multiple resistance was due to many Klebsiellae and unidentifiable coliforms resistant to ampicillin only. This is supported by the results given in table $\mathrm{V}$ in which frequency of multiple resistance is related to individual antibiotics. Resistance to ampicillin alone was very common whereas resistance to each of the other three antibiotics was usually associated with multiple resistance, especially in the case of chloramphenicol to which more than $75 \%$ of the strains were resistant to three or four antibiotics.

The commonest pair of antibiotics with resistance occurring together was ampicillin/streptomycin (16.9\% of resistant strains) and the commonest triple determinant was ampicillin/streptomycin/tetracycline (15.4\%).

Despite the complexity of coliform types in sewage and the problems of their origin, the earlier observations of large differences between the proportions of antibiotic-resistant coliform bacilli in general hospital and in domestic sewage can be shown to be valid for organisms of faecal origin by considering $E$. coli 
type I strains alone. From the proportion of isolates with the biochemical properties of $E$. coli, it was possible to estimate the numbers of faecal $E$. coli in

TABLE V

Multiple resistance associated with particular antibiotics in 2713 resistant coliform bacilli from 23 sewer swabs

\begin{tabular}{|c|c|c|c|c|c|}
\hline \multirow[b]{2}{*}{ Antibiotic } & \multirow{2}{*}{$\begin{array}{l}\text { Number } \\
\text { of } \\
\text { resistant } \\
\text { strains }\end{array}$} & \multicolumn{4}{|c|}{ Percentage of coliform bacilli resistant to } \\
\hline & & $\begin{array}{c}\text { one } \\
\text { antibiotic }\end{array}$ & $\begin{array}{c}\text { two } \\
\text { antibiotics }\end{array}$ & $\begin{array}{c}\text { three } \\
\text { antibiotics }\end{array}$ & $\begin{array}{c}\text { four } \\
\text { antibiotics }\end{array}$ \\
\hline $\begin{array}{l}\text { Ampicillin } \\
\text { Streptomycin } \\
\text { Chloramphenicol } \\
\text { Tetracyclines }\end{array}$ & $\begin{array}{r}1973 \\
1534 \\
370 \\
1194\end{array}$ & $\begin{array}{r}40 \cdot 2 \\
10 \cdot 9 \\
1 \cdot 4 \\
20 \cdot 1\end{array}$ & $\begin{array}{l}27 \cdot 5 \\
45 \cdot 9 \\
20 \cdot 5 \\
23 \cdot 1\end{array}$ & $\begin{array}{l}24 \cdot 8 \\
33 \cdot 9 \\
38 \cdot 4 \\
44 \cdot 5\end{array}$ & $\begin{array}{r}7 \cdot 5 \\
9 \cdot 6 \\
39 \cdot 7 \\
12 \cdot 3\end{array}$ \\
\hline Any of above & 2713 & $44 \cdot 4$ & $29 \cdot 5$ & $20 \cdot 7$ & $5 \cdot 4$ \\
\hline
\end{tabular}

sewage samples and table VI compares counts on four samples from isolated sewers of hospitals A and B, and from four samples from isolated sewers from the adjacent domestic areas. Although the numbers of faecal E. coli from these

TABLE VI

Escherichia coli type I from hospital and domestic sewers

\begin{tabular}{|c|c|c|c|c|c|}
\hline \multirow{3}{*}{$\begin{array}{c}\text { Source } \\
\text { and number } \\
\text { of samples }\end{array}$} & \multicolumn{4}{|c|}{ Coliform bacilli and $E$. coli isolated from } & \multirow{3}{*}{$\begin{array}{l}\text { Percentage } \\
\text { tetracycline- } \\
\text { resistant } \\
\text { strains of } \\
E \text {. coli faecal } \\
\text { type I }\end{array}$} \\
\hline & \multicolumn{2}{|c|}{ MacConkey agar } & \multicolumn{2}{|c|}{ MacConkey agar + tetracycline } & \\
\hline & $\begin{array}{c}\text { Average } \\
\text { counts of } \\
\text { total } \\
\text { coliform } \\
\text { bacilli* }\end{array}$ & $\begin{array}{c}\text { Percentage } \\
\text { of } E \text {. coli } \\
\text { type I }\end{array}$ & $\begin{array}{l}\text { counts of } \\
\text { tetracycline- } \\
\text { resistant } \\
\text { coliform } \\
\text { bacilli* }\end{array}$ & $\begin{array}{c}\text { Percentage } \\
\text { of } E \text {. Coli } \\
\text { type I }\end{array}$ & \\
\hline $\begin{array}{l}\text { Hospital } \\
\text { (4 samples) }\end{array}$ & $7 \cdot 6 \times 10^{7}$ & $5 \cdot 6$ & $1.3 \times 10^{7}$ & $19 \cdot 7$ & $60 \cdot 4$ \\
\hline $\begin{array}{l}\text { Domestic } \\
\text { (4 samples) }\end{array}$ & $7.0 \times 10^{7}$ & $18 \cdot 0$ & $1.1 \times 10^{4}$ & 88.0 & 0.8 \\
\hline
\end{tabular}

* Geometric means.

hospital sewers was only one third of those from domestic sewers, the proportion of tetracycline-resistant faecal strains in these hospital sewers was 60 times greater than that in the adjacent domestic sewers.

\section{Resistance to other antibiotics}

Direct sensitivity tests showed that coliform bacilli resistant to antibiotics other than those incorporated in media were often numerous in sewage. All 
samples contained many resistant to carbenicillin and to cephaloridine, and moderate numbers resistant to sulphonamide and kanamycin. Resistance to nalidixic acid was found in a few organisms in about half of the samples from hospital and domestic sources. Coliform bacilli resistant to nitrofurantoin, gentamicin, and colistin were seldom found.

TABLE VII

$R$ factors in coliform bacilli of different biochemical types

\begin{tabular}{l|cc}
\hline Biochemical type & $\begin{array}{c}\text { Number of } \\
\text { strains tested }\end{array}$ & $\begin{array}{c}\text { Transfer } \\
\text { demonstrated } \\
\text { (percentage) }\end{array}$ \\
\hline Esch. coli type I & 369 & $63 \cdot 1$ \\
Citrobacter & 41 & $46 \cdot 3$ \\
Klebsiella & 77 & $33 \cdot 8$ \\
Enterobacter & 47 & $27 \cdot 7$ \\
"Others" & 108 & $27 \cdot 8$ \\
\hline
\end{tabular}

\section{$R$ factors in sewage}

Of 1000 antibiotic resistant coliform bacilli isolated during this study from a variety of sewers and from rivers and streams, $413(41.3 \%)$ transferred resistance to a laboratory recipient. Of these, 642 were also tested for biochemical identification. The presence of $\mathrm{R}$ factors in the different types of coliform bacilli is shown in table VII. $\mathbf{R}$ factors were demonstrated much more often $(63 \%)$ in faecal type $E$. coli than in other biochemical types $(32 \%)$.

\section{TABLE VIII}

$R$ factors carried and multiple determinants transferred by coliform bacilli from different sources

\begin{tabular}{|c|c|c|c|c|c|c|c|}
\hline \multirow{2}{*}{ Source } & \multirow{2}{*}{$\begin{array}{l}\text { Number } \\
\text { of strains } \\
\text { tested }\end{array}$} & \multirow{2}{*}{$\begin{array}{l}\text { Percentage } \\
\text { of } \\
\text { R-factors }\end{array}$} & \multicolumn{5}{|c|}{$\begin{array}{l}\text { Percentage of } \mathbf{R} \text { factors with indicated } \\
\text { number of determinants: }\end{array}$} \\
\hline & & & 1 & 2 & 3 & 4 & 5 \\
\hline $\begin{array}{l}\text { Isolated sewers } \\
\text { Hospitals A \& B } \\
\text { Domestic A \& BC }\end{array}$ & $\begin{array}{l}61 \\
51\end{array}$ & $\begin{array}{l}42 \cdot 6 \\
41 \cdot 2\end{array}$ & $\begin{array}{r}3 \cdot 8 \\
38 \cdot 1\end{array}$ & $\begin{array}{l}38 \cdot 5 \\
14 \cdot 3\end{array}$ & $\begin{array}{l}30 \cdot 8 \\
14 \cdot 3\end{array}$ & $\begin{array}{l}23 \cdot 1 \\
28 \cdot 6\end{array}$ & $\begin{array}{l}3 \cdot 8 \\
4 \cdot 8\end{array}$ \\
\hline Sewers of all types & 1000 & $41 \cdot 3$ & $24 \cdot 5$ & $25 \cdot 2$ & $22 \cdot 1$ & $18 \cdot 2$ & $10 \cdot 1$ \\
\hline
\end{tabular}

Although the incidence of resistant organisms was much higher in hospital than in domestic sewage, the proportion of resistant strains in which an $\mathrm{R}$ factor was demonstrated was almost identical for both sources. Table VIII shows the results of $\mathrm{R}$ factor transfer tests on 112 coliform strains obtained from the isolated sewers of hospitals $\mathrm{A}$ and $\mathrm{B}$ and their adjacent domestic areas, the numbers of antibiotic determinants mobilised as $\mathbf{R}$ factors in these groups, and 
the average results for the 1000 coliform strains tested which are shown for comparison.

Although the incidence of $\mathbf{R}$ factors in resistant coliform strains was very similar in hospital and domestic sewage, the patterns of resistance determinants on the $\mathbf{R}$ factors from hospitals were more complex than those from domestic sources. Multiple resistance was transferred in $96.5 \%$ of the $\mathrm{R}$ factors found in hospital isolates, compared with $61.9 \%$ of those from domestic sources. Of the $\mathrm{R}$ factors transferring resistance to only one antibiotic almost all transferred tetracycline resistance and they were much more common in domestic sewage $(38 \%)$ than hospital sewage $(3.5 \%)$. The greater the number of antibiotics to which an organism was resistant, the greater was the likelihood that it possessed an $\mathrm{R}$ factor: $15 \%$ of organisms resistant to one antibiotic carried an $\mathrm{R}$ factor, $40 \%$ of organisms resistant to two, $58 \%$ of organisms resistant to three, and $68 \%$ of organisms resistant to four or more antibiotics. As would be expected, in some donor organisms only some of the resistance determinants were transferred, while fragmentation of some $\mathrm{R}$ factors seemed to occur very easily; the most notable example was that of the donor-resistance pattern ampicillin/ streptomycin/tetracycline/sulphonamide for which $\mathbf{R}$ factors carrying 12 different combinations of the four determinants were demonstrated.

The proportions of the donors that transferred resistance to particular antibiotics were: tetracycline $(76 \%)$, streptomycin $(63 \%)$, sulphonamides (46\%), ampicillin (39\%) and chloramphenicol (36\%). The figure for chloramphenicol seems high, considering how little chloramphenicol is used in and out of hospital, and is a reminder that organisms carrying $\mathbf{R}$ factors for multiple resistance can be selected by other unrelated antibiotics.

\section{$R$-factor transfer in sewage}

The frequency of coliform bacilli containing $\mathrm{R}$ factors among the isolates from the inlet to the sewage-treatment works was $46 \%$, slightly more than in most other sewers studied. However, the difference was very small and, moreover, laboratory tests-which will be reported elsewhere-have shown that $\mathbf{R}$ factors could be transferred in sewage only at relatively high temperatures $\left(37^{\circ} \mathrm{C}\right)$ and when nutrient was added. We therefore conclude that under normal conditions in sewers transfer is most unlikely to be an important factor in the ecology of $\mathbf{R}$ factors.

\section{Discussion}

The results of this survey support the view that $\mathrm{R}$-factor-carrying intestinal bacteria are widespread in the general population (Sturtevant, Cassell and Feary, 1971) and confirm the conclusions drawn from other studies (Datta, 1969; Moorhouse, 1969; Wiedemann, Knothe and Hölzer, 1969; Linton et al., 1972).

Many factors may contribute to the maintenance of this reservoir of antibiotic-resistant bacteria in the general population. Some foodstuffs are contaminated by enterobacteria that carry $\mathbf{R}$ factors (Moorhouse, O'Grady and O'Connor, 1969; Cooke et al., 1971; Jones, 1971; Walton and Lewis, 1971). 
The unhygienic disposal of excreta may be important (Koonkhamlert et al., 1972; Woods, Marcos and Hendry, 1972). In sequential investigations of volunteers whose faeces initially contained a few R-factor-carrying coliforms, we found that similar organisms with the same resistance patterns occasionally became predominant in the faeces. We cannot explain these apparently spontaneous changes. They might perhaps have been caused by variations in diet or even by the unintentional ingestion of antibiotics in food. At all events, there is no doubt that treatment with antibiotics, even for short periods, may profoundly influence the bowel flora for a long time afterwards. Anderson, Gillespie and Richmond (1973) showed that volunteers treated with ampicillin or tetracycline for 5 days after swallowing multi-resistant R-factor-carrying organisms continued to excrete the same R factors, in donor or other bacteria, for periods of up to 3 months. This was about 20 times longer than after ingestion of the same organisms by the same volunteers without chemotherapy.

Many workers have reported a higher incidence of antibiotic-resistant intestinal bacteria among in-patients of hospitals than among people outside (Salzman and Klemm, 1966; Lewis, 1968; Datta, 1969; Cooke et al., 1971; Lebek, 1972). The present study of sewage from hospital and domestic sources is certainly in accord with these reports and with the observations of Grabow and Prozesky (1973) that R-factor-carrying strains with multiple-resistance patterns are much more abundant in hospital waste water than in domestic sewage. These authors found a lower incidence $(15 \%)$ of transferable drugresistance in the resident organisms from domestic sewage than we observed (table VIII); but in other respects these two studies are in general agreement.

Our investigations of the fate of R-factor-carrying bacteria in the sewage treatment works and after discharge into the River Avon and the Severn estuary will be described in detail in another paper. Many millions of R-factorcarrying bacteria are discharged daily into the River Severn but they do not survive very long. Smith $(1970,1971)$ found bacteria with $R$ factors in most of his samples from British rivers and coastal waters, but he showed that they died rapidly when suspended in sea water. Efficient methods of sewage treatment are obviously desirable but there is no evidence to suggest that contaminated rivers or coastal waters are major sources of antibiotic-resistant bacteria in the general human population. Grabow and Prozesky (1972) concluded from their studies in South Africa that the disposal of hospital waste water into city sewage was an important health hazard. We have reached a different conclusion from a consideration of the total numbers of $\mathrm{R}$ factors entering the Bristol sewage treatment works. About 21 million gallons $\left(100,000 \mathrm{~m}^{3}\right)$ of sewage is dealt with daily by the treatment works and our calculations show that this volume contains about $8.8 \times 10^{14}$ coliform bacteria carrying $\mathrm{R}$ factors. From the volumes and composition of hospital sewage and the average bed-occupancy of the Bristol hospitals considered as a proportion of the total population in the Bristol area, we calculate that less than $5 \%$ of the $\mathrm{R}$ factors discharged into the city sewage are derived from people in hospital even though the concentration of $R$-factor-carrying bacteria is much higher in sewage from hospitals than from any other source. 
The extent to which $\mathbf{R}$ factors and their transfer augment the numbers of antibiotic-resistant bacteria in the general population is still not clear. Our results suggest that, when the population of an area is viewed as a whole, it is the healthy population outside hospital that constitutes the main reservoir of $\mathrm{R}$ factors. Certainly the high incidence of resistant strains in sewage from hospitals reflects the use of antibiotics in the hospitals; but the prevalence of resistant strains in people outside hospitals suggests that no one escapes the selective effects of antibiotics, whether or not they are being treated with them.

\section{SUMMARY}

One-hundred and one samples from a wide variety of sewers and waterdrainage channels in Bristol, including some sewers that separately drained hospital and domestic premises, were examined for antibiotic-resistant coliform bacilli and for $\mathrm{R}$ factors. The antibiotic-sensitivity patterns of over 3000 coliform bacilli isolated were obtained and 1000 resistant strains were tested for R-factor transfer.

Hospital sewage contained more coliform bacilli with much higher proportions of resistant bacteria, more $\mathrm{R}$ factors, and a greater proportion of $\mathrm{R}$ factors carrying multiple resistance, than sewage from domestic and other sources. Despite these findings, it was calculated that less than $5 \%$ of the $\mathrm{R}$ factors in the sewage output of the City of Bristol originate in hospitals. The normal, healthy population appears to be by far the greatest reservoir of $\mathrm{R}$ factors in the community.

We wish to acknowledge the co-operation of the staff of the City Engineer's Department of Bristol for the collection of sewer samples, and in particular, Mr P. H. Steel and Mr G. P. Hall for organising the programmes. We are also indebted to Mrs $\mathrm{H}$. Clements for valuable technical assistance. The work was supported by grants from the Research Committee of the United Bristol Hospitals and from the Medical Research Council.

\section{REFERENCES}

Anderson, J. D., Gillespie, W. A. AND Richmond, M. H. 1973. Chemotherapy and antibiotic-resistance transfer between bacteria in the human gastro-intestinal tract. J. med. Microbiol., 6, 461.

Cooke, E. M., Shooter, R. A., Breaden, A. L. AND O'Farrell, S. M. 1971. Antibiotic sensitivity of Escherichia coli isolated from animals, food, hospital patients, and normal people. Lancet, $2,8$.

Cowan, S. T. AND Steel, K. J. 1965. Manual for the identification of medical bacteria, London.

DatTA, N. 1969. Drug resistance and R-factors in the bowel bacteria of London patients before and after admission to hospital. Br. med.J., 2, 407.

Department of Health AND Soctal Security (1969). The bacteriological examination of water supplies. (Reports on Public Health and Medical Subjects, no. 71, 4th ed.) London.

Grabow, W. O. K. aNd Prozesky, O. W. 1972. Coliform bacteria with transferable drugresistance in hospital waste water and city sewage. S. Afr. med. J., 46, 1769.

Grabow, W. O. K. aND Prozesky, O. W. 1973. Drug-resistance of coliform bacteria in hospital and city sewage. Antimicrob. Agents Chemother., 3, 175.

JONES, A. M. 1971. Escherichia coli in retail samples of milk and their resistance to antibiotics. Lancet, $2,347$. 
Koonkhamlert, C., Limsuwan, A., Simasathien, P. And Sawyer, W. D. 1972. Infectious drug resistance in Thailand. III. Prevalence of drug-resistant Escherichia coli in the intestinal flora of urban and rural children. J. med. Ass. Thailand, 55, 627.

LeBeK, G. 1972. Epidemiological investigations of R-factors in man and animals in Switzerland. In Bacterial plasmids and antibiotic resistance, edited by V. Krčméry, L. Rosival and T. Watanabe, New York, p. 47.

LEWIS, M. J. 1968. Transferable drug resistance and other transferable agents in strains of Escherichia coli from two human populations. Lancet, 2, 1389.

Linton, K. B., Lee, P. A., Richmond, M. H., Gillespie, W. A., Rowland, A. J. AND BAKER, V. N. 1972. Antibiotic resistance and transmissible R-factors in the intestinal coliform flora of healthy adults and children in an urban and a rural community. J. Hyg., Camb., 70, 99.

MoORHOUSE, E. C. 1969. Transferable drug resistance in enterobacteria isolated from urban infants. Br. med. J., 2, 405.

Moorhouse, E. C., O'Grady, M. F. AND O'Connor, H. 1969. Isolation from sausages of antibiotic-resistant Escherichia coli with R-factors. Lancet, 2, 50.

Saltzman, T. C. AND KlemM, L. 1966. Transferable drug resistance (R-factors). In Enterobacteriaceae: relationship to nosocomial infections. Antimicrob. Agents Chemother., p. 212.

SMITH, H. W. 1970 . Incidence in river water of Escherichia coli containing R-factors. Nature, Lond., 228, 1286.

SMITH, H. W. 1971. Incidence of $\mathrm{R}^{+}$Escherichia coli in coastal bathing waters of Britain. Nature, Lond., 234, 155.

Sturtevant, A. B., Cassell, G. H. ANd Feary, T. W. 1971. Incidence of infectious drug resistance among faecal coliforms isolated from raw sewage. Appl. Microbiol., 21, 487.

Walton, J. R. AND LewIS, L. E. 1971. Contamination of fresh and cooked meats by antibiotic-resistant coliform bacteria. Lancet, 2, 255.

Wiedemann, B., KNOTHE, H. AND HölzeR, P. 1969. A study of the distribution of R-factors. Zentbl. Bakt. ParasitKde, I Abt. Orig., 212, 97.

Woods, D. R., Marcos, D. AND Hendry, D. A. 1972. The incidence of R factors among coliform bacteria. S. Afr. med.J., 46, 189. 